should be the aim of all those responsible for the care of the child and his family. As the mothers of $29(58 \%)$ abused children were referred to the maternity hospital social worker, it is clear that social work help alone cannot prevent battering. There seems to be a need for co-ordinating all disciplines, both in hospital and in the community, to provide preventive help for the parents. Treatment projects in different settings have already shown that prevention is possible. ${ }^{16-18}$ The use of data such as ours merely to compile "at-risk" registers would result only in despondency and frustration.

The research was funded by Action Research for the Crippled Child. JR is seconded by. Oxfordshire social services department. Secretarial help was given by Miss Alison van Dedem Edwards, who is funded by the Oxford Regional Health Authority locally organised research scheme. We thank all the staff at the John Radcliffe Maternity Hospital whose notes made this study possible, the family doctors for their kind interest and co-operation, and Dr C Ounsted and Dr J Lindsay for their advice and encouragement.

\section{References}

${ }^{1}$ Lynch, M A, et al, Developmental Medicine and Child Neurology, 1976, $18,759$.

${ }^{2}$ Lynch, M A, and Ounsted, C, in Child Abuse and Neglect. The Family and the Community, ed R E Helfer and C H Kempe, ch XI. Cambridge, Mass, Ballinger, 1976.
${ }^{3}$ Howat, P, Paper on predicting and preventing child abuse given at Tunbridge Wells Study Group, October 1976.

${ }^{4}$ Davis, P A, et al, Clinics in Developmental Medicine, No 44-45. Medical Care of New-born Babies. London, Spastics International Medical Publications and Heinemann, 1972.

${ }^{5}$ Lynch, M A, Journal of Maternal and Child Health, 1976, 1, 1.

${ }^{6}$ Smith, S M, et al, British Medical fournal, 1976, 4, 388.

${ }^{7}$ National Society for the Prevention of Cruelty to Children, Case Work and Development Department, Registers of Suspected Non-accidental Injury London, NSPCC, 1975.

${ }^{8}$ Lynch, M A, Lancet, 1975, 2, 317.

${ }^{9}$ Baldwin, J A, and Oliver, J E, British fournal of Preventive and Social Medicine, 1972, 29, 4.

10 Ounsted, C, and Lynch, M A, in Child Abuse and Neglect. The Family and the Community, ed R E Helfer and C H Kempe, ch VI. Cambridge, Mass, Ballinger, 1976.

${ }^{11}$ Klaus, M, and Kennell, J, fournal of Pediatric Clinics of North America, $1970,17,1016$

${ }^{12}$ Kempe, C H, Archives of Disease in Childhood, 1971, 46, 28.

${ }^{13} \mathrm{Gray}, \mathrm{J}$, et al, in Child Abuse and Neglect. The Family and the Community, ed R E Helfer and C H Kempe, ch XIX. Cambridge, Mass, Ballinger, 1976.

${ }^{14}$ Fanaroff, A A, Kennell, J H, and Klaus, M H, Pediatrics, 1972, 49, 287.

15 Helfer, R E, and Kempe, C H, (editors), Helping the Battered Child and his Family, ch 5. Philadelphia and Toronto, Lippincott, 1972.

${ }^{16}$ Ounsted, C, Oppenheimer, R, and Lindsay, J, Developmental Medicine and Child Neurology, 1974, 16, 4.

${ }^{17}$ Beswick, K, Lynch, M A, and Roberts, J, British Medical fournal, 1976, 2, 800 .

${ }^{18}$ Kempe, $\mathrm{C} \mathrm{H}$, and Helfer, R E, (editors), Helping the Battered Child and his Family, ch 3. Philadelphia and Toronto, Lippincott, 1972.

(Accepted 29 November 1976)

\title{
Survey of safety and health care in British medical laboratories
}

\author{
J M HARRINGTON, H S SHANNON
}

British Medical fournal, 1977, 1, 626-628

establishing regulations for codes of safe practice rather than relying merely on recommendations as at present.

\section{Summary}

A retrospective postal survey of 24000 medical laboratory workers in England, Wales, and Scotland showed highly variable standards of safety and health care. Preemployment health screening was offered to two-thirds of employees, the physicians being the least likely to be examined $\left(15^{\circ}{ }^{\circ}\right)$. Scottish laboratories provided better safety control than English and Welsh laboratories, while Public Health Service Laboratories had a better record than National Health Service establishments. Mouth pipetting is still practised in $65^{\circ}{ }^{\circ}$, of English and Welsh laboratories, and the use of protective clothing is rarely compulsory. The servicing of safety cabinets is often inadequate. Known and suspected carcinogens are still apparently used in a few laboratories $\left(2-10^{\circ}\right)$.

In view of the wide variation in standards among laboratories, urgent consideration should be given to

TUC Centenary Institute of Occupational Health, London School of Hygiene and Tropical Medicine, London WC1E 7HT

J M HARRINGTON, MD, MRCP, lecturer in occupational medicine (present address: Environmental Hazards Activity, Cancer and Birth Defects Division, Bureau of Epidemiology, Centre for Disease Control, Atlanta, Georgia 30333, USA)

H S SHANNON, MSC, FSS, statistician

\section{Introduction}

Medical laboratory workers are exposed to a wide variety of occupational hazards. These include specific risks, such as laboratory-acquired infections, ${ }^{12}$ as well as the more general risks of laboratory practice such as fires, explosions, gassings, and physical injury. ${ }^{3}{ }^{4}$ Few epidemiological studies of laboratory populations have been undertaken. In 1957 Reid $^{5}$ noted an increased risk among British medical laboratory workers of acquiring tuberculosis of between two and nine times the national rates. Laboratory workers are also exposed to many chemicals. Bladder tumours occur more often in medical and paramedical workers, ${ }^{6}$ and the death rate among professional chemists in the USA from lymphomata and carcinoma of the pancreas is higher.?

Our report is part of a three-year survey of the health of British medical laboratory workers. Tuberculosis incidence rates are two to five times greater than in the general population, ${ }^{8}$ though a mortality study showed no clear-cut picture of increased cancer mortality, except possibly for lymphomata. ${ }^{9}$ Suicide rates suggested that access to chemicals might influence the high mortality rate, particularly with regard to the method of suicide.

In view of these real and potential occupational hazards, we tried to assess the standard of health care available to laboratory workers in the National Health Service (NHS), Public Health 
TABLE II-Percentage provision of staff health care in English and Welsh Laboratories, 1971 (Scottish figures, 1973, in parentheses) by grade of staff (standardised for length of service)

\begin{tabular}{|c|c|c|c|c|c|c|c|}
\hline \multirow{2}{*}{$\begin{array}{l}\text { Grade of } \\
\text { staff }\end{array}$} & \multirow{2}{*}{$\begin{array}{l}\text { '., Undergone } \\
\text { chest radiography } \\
\text { at start of } \\
\text { employment }\end{array}$} & \multirow{2}{*}{$\begin{array}{c}o_{*} \text { Ever given } \\
\text { BCG } \\
\text { vaccination }\end{array}$} & \multirow{2}{*}{$\begin{array}{c}\text { “. Undergone } \\
\text { examination } \\
\text { before } \\
\text { employment }\end{array}$} & \multicolumn{3}{|c|}{ Vaccinations offered } & \multirow{2}{*}{$\begin{array}{l}\text { TB test at start } \\
\text { of employment }\end{array}$} \\
\hline & & & & Smallpox & TAB & Cholera & \\
\hline $\begin{array}{l}\text { Medical } \\
\text { Scientific } \\
\text { Technical } \\
\text { Other }\end{array}$ & $\begin{array}{l}41 \cdot 7(43 \cdot 7) \\
53 \cdot 6(52 \cdot 7) \\
72 \cdot 2(69 \cdot 7) \\
59 \cdot 6(66 \cdot 5)\end{array}$ & $\begin{array}{l}27 \cdot 9(35 \cdot 3) \\
46 \cdot 3(62 \cdot 8) \\
55 \cdot 9(71 \cdot 4) \\
25 \cdot 1(40 \cdot 5)\end{array}$ & $\begin{array}{l}18 \cdot 0(8 \cdot 6) \\
33 \cdot 7(22 \cdot 0) \\
44 \cdot 2(29 \cdot 5) \\
43 \cdot 1(27 \cdot 9)\end{array}$ & $\begin{array}{l}42 \cdot 7(32 \cdot 7) \\
41 \cdot 9(29 \cdot 8) \\
51 \cdot 8(31 \cdot 6) \\
37 \cdot 1(28 \cdot 8)\end{array}$ & $\begin{array}{l}28 \cdot 4(24 \cdot 1) \\
23 \cdot 1(19 \cdot 4) \\
31 \cdot 5(24 \cdot 6) \\
17 \cdot 7(20 \cdot 9)\end{array}$ & $\begin{array}{r}12 \cdot 3(7 \cdot 2) \\
6 \cdot 7(5 \cdot 3) \\
6 \cdot 5(4 \cdot 5) \\
4 \cdot 4(2 \cdot 8)\end{array}$ & $\begin{array}{l}19 \cdot 3(16 \cdot 5) \\
25 \cdot 7(14 \cdot 0) \\
48 \cdot 8(37 \cdot 4) \\
26 \cdot 8(25 \cdot 7)\end{array}$ \\
\hline
\end{tabular}

TABLE I-Percentage provision of staff health care in English and Welsh laboratories, 1971 (Scottish figures, 1973, in parentheses) by length of service

\begin{tabular}{|c|c|c|c|c|c|c|c|}
\hline \multirow{2}{*}{$\begin{array}{l}\text { Years employed } \\
\text { in laboratory }\end{array}$} & \multirow{2}{*}{$\begin{array}{l}\text { "' Undergone } \\
\text { chest radiography } \\
\text { at start of } \\
\text { employment }\end{array}$} & \multirow{2}{*}{$\begin{array}{c}\text { ". Ever given } \\
\text { BCG } \\
\text { vaccination }\end{array}$} & \multirow{2}{*}{$\begin{array}{c}\text { Undergone } \\
\text { examination } \\
\text { before } \\
\text { employment }\end{array}$} & \multicolumn{3}{|c|}{ Vaccinations offered } & \multirow{2}{*}{$\begin{array}{l}\text { TB test at start } \\
\text { of employment }\end{array}$} \\
\hline & & & & Smallpox & TAB & Cholera & \\
\hline $\begin{array}{c}<5 \\
5-9 \\
10\end{array}$ & $\begin{array}{l}64 \cdot 5(61 \cdot 1) \\
70 \cdot 3(69 \cdot 5) \\
66 \cdot 2(73 \cdot 7)\end{array}$ & $\begin{array}{l}50.9(68 \cdot 7) \\
41.6(58.1) \\
17.9(30 \cdot 7)\end{array}$ & $\begin{array}{l}41 \cdot 4(24 \cdot 6) \\
43 \cdot 3(26 \cdot 3) \\
41 \cdot 0(33 \cdot 7)\end{array}$ & $\begin{array}{l}35.9(23.6) \\
56.5(29 \cdot 1) \\
80.6(60.2)\end{array}$ & $\begin{array}{l}22 \cdot 1(18 \cdot 8) \\
30 \cdot 9(23 \cdot 4) \\
43 \cdot 5(40 \cdot 2)\end{array}$ & $\begin{array}{l}6 \cdot 0(3 \cdot 9) \\
6 \cdot 2(4 \cdot 7) \\
8 \cdot 4(6 \cdot 8)\end{array}$ & $\begin{array}{l}38 \cdot 1(23 \cdot 8) \\
41 \cdot 2(30 \cdot 5) \\
40 \cdot 7(35 \cdot 7)\end{array}$ \\
\hline Total & $64.9(65 \cdot 8)$ & $43.5(62 \cdot 5)$ & $41 \cdot 3(26 \cdot 6)$ & $45 \cdot 8(30 \cdot 6)$ & $26 \cdot 5(23 \cdot 1)$ & $6 \cdot 3(4 \cdot 5)$ & $38 \cdot 4(30 \cdot 4)$ \\
\hline
\end{tabular}

$\chi^{2}$ tests for differences in percentage provisions between various grades of staff almost invariably show such differences to be highly significant. This, however, is to be expected in large populations, so it is reasonable to compare the percentages without recourse to statistical tests.

Laboratory Service (PHLS), and the National Blood Transfusion Service (NBTS). We also assessed laboratory safety procedures.

\section{Materials and methods}

A retrospective postal survey of people working in NHS, PHLS, and NBTS laboratories was undertaken in England and Wales in 1971 and in Scotland in 1973. Questions were asked of each respondent about health examinations before employment and exposure to known carcinogens such as $\beta$-naphthylamine, benzidine, and o-tolidene. Laboratory directors were asked to complete a separate questionnaire that inquired about codes of laboratory practice such as safety training, hygiene standards, protective clothing, and the servicing of centrifuges and safety cabinets.

With the help of the Department of Health and Social Security, we identified 368 group laboratories in England and Wales employing an estimated 24000 workers. Three hundred and fifty-two laboratories $(95.7 \%)$ returned batches of questionnaires from 20950 individuals. In the Scottish study all 133 laboratories responded with replies from 3061 persons.

\section{Results}

\section{STAFF HEALTH CARE}

Table I shows the percentage provision of several health-care procedures by length of employment in the laboratory. The standard of care has not improved, indeed there is evidence of deterioration. Less than half the laboratory population had any pre-employment surveillance, and only a minority were offered prophylactic vaccinations. Table II shows the pre-employment medical examinations and chest radiography were least likely to be offered to medical staff.

\section{GENERAL LABORATORY SAFETY}

Figure 1 illustrates the percentage of laboratories in England and Wales and in Scotland that established certain safety measures in their laboratories. The overall impression gained is one of higher standards in Scotland than in England and Wales.

Although most laboratories provided some form of safety training for new staff, only $30 \%$ of English and Welsh laboratories and $44 \%$ of Scottish ones provided both formal teaching and practical instruction at the bench. Microbiology laboratories offered the most formal instruction, while clinical chemistry laboratories provided the least. The larger the laboratory the more likely it was to provide training, though PHLS establishments had more formal training than NHS laboratories. The presence of a formally designated safety officer was strongly associated with safety training $-65 \%$ of laboratories with

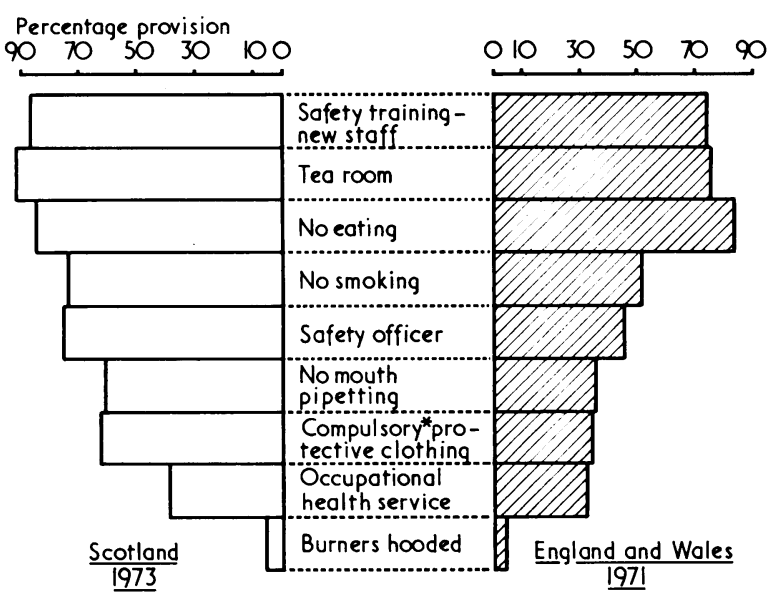

FIG 1-Summary of provision taken by laboratories to improve safety. *Protective clothing is provided for certain specified procedures.

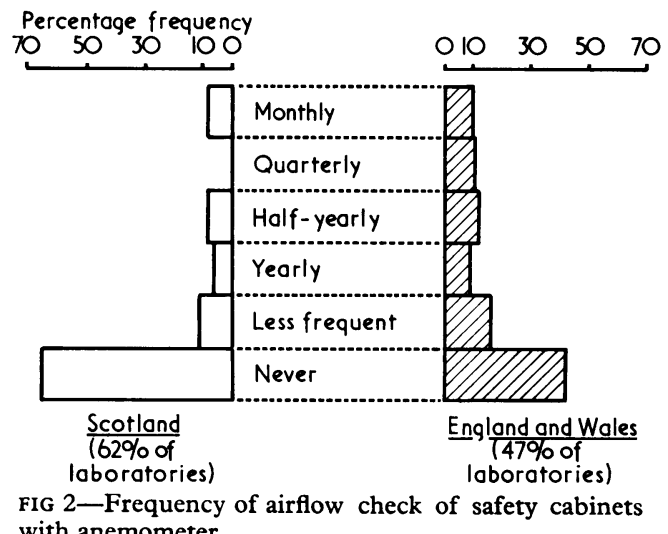

with anemometer.

safety officers provided safety training, whereas such training was available in only $45 \%$ of laboratories not employing such a member of staff.

Most laboratories provided tea rooms but $6 \%$ allowed eating in the laboratory, and 30\% allowed smoking despite such provisions.

Protection of staff from specific laboratory hazards varied: $65 \%$ of English and Welsh laboratories and 38\% of Scottish ones allowed 
mouth pipetting, though the figures for microbiology establishments were $46^{\circ}{ }_{0}$ (England and Wales) and $28^{\circ}{ }_{0}$. (Scotland). Although protective clothing such as gowns, gloves, and masks was available in most laboratories, they were compulsory only in one third of English and Welsh and two-thirds of Scottish laboratories even when the procedure was known to be hazardous.

In an attempt to estimate laboratory practice regarding scientific apparatus, specific questions were asked about the maintenance of centrifuge and safety cabinets (fig 2). Although $65^{\circ}{ }_{0}$ of laboratories had their centrifuges maintained by the manufacturer's agent, the mean interval between servicing was nine months in England and Wales and six months in Scotland. Half the laboratories surveyed possessed safety cabinets but two-thirds of Scottish and $40 \%$ of English and Welsh laboratories never checked the airflow with an anemometer (fig 2). It is recommended practice that when tuberculous material is being handled the air flow should be checked weekly. ${ }^{11}$

\section{USE OF DANGEROUS CHEMICALS}

One question asked about dangerous chemicals was, "During 1971 (1973 in Scotland) have you handled any of the following chemicals ?" The list included four known or suspected carcinogens and one dyestuff, aurantia, known to be highly explosive in the dry state.

In England and Wales, $2 \%$ of medical and technical staff replied that they had handled $\beta$-naphthylamine during the preceding year; $7.3 \%$ of technicians and $4.8 \%$ of doctors had used benzidine; and $3 \%$ of laboratory staff had contact with o-dianisidine. The highly explosive aurantia was still used by $1 \%$ of staff. In Scotland the percentages were similar: $2^{\circ}$ had used $\beta$-naphthylamine, $6^{\circ}$ of technicians and $3^{\circ}{ }_{0}$ of doctors handled benzidine, $10 \%$ of technicians and $5 \%$ of doctors handled o-tolidine, and $2 \%$ of staff had contact with o-dianisidine. Aurantia was still used by $1 \%$ of staff.

\section{Discussion}

Postal inquiries suffer from many methodological problems. Non-response was not, however, a problem in this study except for London teaching hospitals. Nevertheless, verification of questionnaire responses is difficult and the results should be viewed in that context.

Codes of practice for safe working in medical laboratories are well established. ${ }^{1011}$ Our inquiry suggests that codes are either not uniformly accepted or else, if accepted, not practised. Screening before employment is inadequate. Chest radiography, medical examination, and tuberculosis skin testing are not uniformly offered to all new employees, particularly medical staff. In view of the continuing problem of occupationally acquired tuberculosis in this population ${ }^{8}$ such provisions should be universal.

Laboratory practice lacked uniformity. Some laboratories placed great emphasis on safety, and Scottish laboratories were more likely to follow recommended practice than English and Welsh laboratories. Anecdotal evidence suggests that this is not explained by national improvements in the two years between the studies. PHLS laboratories have a better record of safe working practice than NHS establishments. This is to be expected in view of their close-knit administrative structure and their greater emphasis on microbiological investigations. The larger laboratories not only had better safety control but also were more likely to have appointed safety officers.

Analysis of specific practices such as allowing eating or smoking in the laboratory showed that they were invariably related to size of laboratory as well as the laboratory director's attitude. Mouth pipetting is recognised in all safety manuals as dangerous. ${ }^{12}{ }^{13}$ Nevertheless, over half the laboratories surveyed permitted it. Protective clothing was compulsory for specific procedures in only one-third of laboratories.

Safety cabinets are potentially even more hazardous. The apparatus is almost invariably used for high risk procedures, yet air-flow checks with an appropriate instrument such as an anemometer were rarely conducted. In addition, known carcinogens continue to be used in a few laboratories.
There has been some delay since the study period and the publication of this report. We believe that safety standards have not notably improved in the interim-an impression confirmed by the report of the Working Party on the Laboratory Use of Dangerous Pathogens, ${ }^{14}$ which recommended that "general guidance on safety in laboratories should be drawn up and applied."

\section{Conclusions}

The overall impression gained is one of highly variable safety and health care. Many laboratories adhere to recognised safety practice $^{11}$ but the fact that others are extremely lax suggests that recommendations for safety procedures may need to be replaced in some measure by regulations or an approved code of practice. There is considerable resistance by some pathology personnel to the outside imposition of safety standards into what they consider to be their personal domain. The present series of investigations, however, shows that such ad hoc control is potentially hazardous, and minimum standards for safety and health care need to be established. The Health and Safety at Work Act 1974 included laboratory personnel, but it remains to be seen how the law will be interpreted to protect such employees.

We are indebted to all laboratory staff who completed the survey questionnaires and especially the laboratory directors, hospital authorities, and the Association of Scientific, Technical, and Managerial Staff who ensured a high response rate. The Department of Health and Social Security and the Scottish Home and Health Department financed the study, and we are grateful for their help in establishing the study population. We are especially grateful to $\mathrm{Sir}$ James Howie, Sir Theodore Crawford, and Professor D D Reid for their help in planning the study. Throughout the investigation Professor R S F Schilling and Dr M L Newhouse gave invaluable guidance and encouragement.

This investigation formed part of an MD thesis submitted to the University of London by JMH.

Requests for reprints should be addressed to H S Shannon.

\section{References}

${ }^{1}$ Sulkin, S E, and Pike, R M, American fournal of Public Health, 1951, 41, 1 and 769 .

${ }^{2}$ Phillips, G S, Technical Study No 35. Fort Detrich, US Army Biological Laboratory, 1961.

${ }^{3}$ Skinhöf, P, Scandinavian fournal of Clinical and Laboratory Investigation, $1974,32,27$.

${ }^{4}$ Harrington, J M, Proceedings of the Royal Society of Medicine, 1975, 68, 94.

${ }_{5}^{5}$ Reid, D D, British Medical fournal, 1957, 2, 1.

"Anthony, H M, and Thomas, G M, fournal of the National Cancer Institute, 1970, 45, 879.

${ }^{7} \mathrm{Li}, \mathrm{F}$ P, et al, fournal of the National Cancer Institute, 1969, 43, 1159.

${ }^{8}$ Harrington, J M, and Shannon, H S, British Medical fournal, 1976, 1, 759.

${ }^{9}$ Harrington, J M, and Shannon, H S, British Medical fournal, 1975, 4, 329.

10 Public Health Laboratory Service, Safety in Microbiological Laboratories. London, HMSO, 1971.

${ }^{11}$ Department of Health and Social Security, Safety in Pathology Laboratories. London, DHSS, 1972.

12 Phillips, G B, and Bailey, S P, American fournal of Medical Laboratory Technology, 1966, 32, 127.

${ }^{13}$ Collins, C H, Hartley, E G, and Pilsworth, R, Public Health Laboratory Service Monograph No 6. London, HMSO, 1974.

14 Department of Health and Social Security, Report of Working Party on the Laboratory Use of Dangerous Pathogens, Cmnd 6054. London, DHSS, 1975.

(Accepted 22 December 1976)

ONE HUNDRED YEARS AGO In the Sheriff Court, Glasgow, last week, a father sued the owner of a cock for damages in respect of the death of his child, who had received such injuries from the cock as caused his death. Judgment was given for the defendant, as the cock was not proved to have been of a vicious disposition. (British Medical fournal, 1877.) 